\title{
EFIKASI DIRI REMAJA DALAM MENCEGAH PERILAKU BERESIKO HIV/AIDS DI KOTA BANDUNG
}

\author{
Iin Friyanti Bako
}

Politeknik Kesejahteraan Sosial Bandung, iinfriyantibako@gmail.com

Dwi Yuliani

Politeknik Kesejahteraan Sosial Bandung, dwi_stks@yahoo.co.id

Susilawati

Politeknik Kesejahteraan Sosial Bandung, susilawati.stks@gmail.com

\begin{abstract}
Self-efficacy refers to the cognitive process in the form of decisions, beliefs, or rewards, the extent to which individuals estimate their abilities to carry out certain tasks or actions needed to achieve the desired results. This study aims to obtain an empirical description of: 1) adolescent characteristics, 2) Adolescent cognitive in preventing HIV/AIDS risk behavior, 3) Adolescent motivation in preventing HIV/AIDS risk behavior, 4) Adolescent affection in preventing HIV/AIDS risk behavior, 5) Adolescent selection in preventing HIV/AIDS risk behavior in Bandung city. The method used in this study is a quantitative approach with a descriptive survey method. The number of respondents in this study were 144 adolescents aged 15-18 years living in the city of Bandung. The data collection technique used is a questionnaire technique in the form of a google form. The data analysis technique used is descriptive statistics in the form of data editing, data coding, making summary sheets, making data tabulations and analyzing data. The results showed that adolescent self-efficacy in preventing HIV/AIDS risky behavior was in the moderate category of $71.52 \%$. Shows that respondents have low self-efficacy in an effort to prevent HIV/AIDS risky behavior, especially in the cognitive and motivational aspects, which tend to be in the moderate category.
\end{abstract}

Keywords:

Self-efficacy, HIV/AIDS, Adolescent.

\begin{abstract}
Abstrak
Efikasi diri merujuk pada Proses kognitif berupa keputusan, keyakinan, atau penghargaan sejauh mana individu memperkirakan kemampuan dirinya dalam melaksanakan suatu tugas atau tindakan tertentu yang diperlukan untuk mencapai hasil yang diinginkan. Penelitian ini bertujuan untuk memperoleh gambaran secara empiris tentang: 1)karakteristik remaja, 2) Kognitif remaja dalam mencegah perilaku beresiko HIV/AIDS, 3)Motivasi remaja remaja dalam mencegah perilaku beresiko HIV/AIDS, 4)Afeksi remaja dalam mencegah perilaku beresiko HIV/AIDS, 5)Seleksi remaja dalam mencegah perilaku beresiko HIV/AIDS di kota bandung. Metode yang digunakan dalam penelitian
\end{abstract}


ini adalah pendekatan kuantitatif dengan metode survey deskriptif. Jumlah responden dalam penelitian ini adalah sebanyak 144 remaja usia 15-18 tahun yang tinggal di kota bandung. Teknik pengumpulan data yang digunakan adalah teknik kuesioner berupa google formulir. Teknik analisis data yang digunakan yaitu menggunakan statistic deskriptif berupa editing data, pengkodean data, pembuatan lembar ringkasan, pembuatan tabulasi data serta penganalisisan data. Hasil penelitian menunjukkan bahwa efikasi diri remaja dalam mencegah perilaku beresiko HIV/AIDS berada pada kategori sedang sebesar $71,52 \%$. Menunjukkan bahwa responden memiliki efikasi diri cukup rendah dalam usaha mencegah perilaku beresiko HIV/AIDS, terlebih pada aspek kognitif dan motivasi yang memiliki kecenderungan pada kategori sedang.

\section{Kata Kunci:}

Efikasi diri, HIV/AIDS, Remaja 


\section{PENDAHULUAN}

Pada masa remaja terjadi tahap perkembangan yang sangat penting, baik itu perkembangan biologis maupun fisiologis yang menentukan kualitas sesorang untuk menjadi individu dewasa. Rousseau dalam (Sarwono, 2003) juga mengatakan bahwa usia 15-20 tahun dinamakan masa kesempurnaan remaja dan merupakan puncak perkembangan emosi. Oleh karena itu setiap bangsa membutuhkan remaja yang produktif, kreatif serta kritis akan kemajuan bangsa itu sendiri dan remaja dapat memaksimalkan produktifitas, kreatifitas dan juga memiliki pemikiran yang kritis dapat dicapai bila mereka sehat baik fisik maupun mentalnya.

Masa remaja umumnya dianggap sebagai masa mencoba sesuatu hal baru dan masa dimana meningkatnya keterlibatan dalam perilaku beresiko atau masalah perilaku, termasuk kegagalan sekolah dan kabur dari sekolah, kekerasan remaja, penggunaan narkoba dan perilaku seksual beresiko tinggi. (Biglan, et al., 2004).

Menurut pinukas dalam (Hendriati, 2006), remaja pertengahan usia 15-19 tahun berada dalam fase yang memiliki tugas perkembangan masa pencarian jati diri serta ruang lingkup pergaulan yang semakin meluas dan mengenal lingkungan baru. Kondisi ini cukup rentan mengingat pada masa ini remaja menentukan gambaran dirinya untuk kedepan. Meskipun sebagian besar remaja menjalani tahap perkembangan tanpa cedera, perilaku beresiko untuk beberapa remaja menjadi kronis, meningkatkan kemungkinan masalah pada beberapa hal seperti kesehatan fisik, harapan hidup, penyesuaian psikososial, dan keberhasilan transisi menjuju kedewasaan.
Komnas perlindungan anak di 33 propinsi pada tahun 2010 menyimpulkan bahwa $97 \%$ remaja sekolah menengah atas pernah menonton film porno; $93,7 \%$ remaja pernah berciuman; 62,7\% remaja sekolah menengah atas tidak perawan, dan $21,2 \%$ remaja pernah melakukan aborsi.

Kota Bandung mempunyai permasalahan seks bebas sudah sangat memprihatinkan. Fakta yang terjadi adalah pemberitaan di media bahwa angka permasalahan seks bebas berada pada tingkat yang mengkhawatirkan. Di tahun 2015 dalam kurun waktu 6 bulan, sebanyak 421 anak dan remaja di Kota Bandung melakukan hubungan seks beresiko. Sejalan degan hal itu, hasil survei dari Alfatih Studio yang disampaikan oleh Anggota DPRD Kota Bandung Salmiah Rambe ketika meminta Pemerintah Kota Bandung melakukan pencegahan perilaku seks bebas, menunjukkan bahwa 54\% remaja di Kota Bandung pada tahun 2015 sudah pernah melakukan hubungan seksual dan pergaulan bebas tersebut kerap diiringi dengan perilaku kekerasan.

Menurut Badan Kependudukan dan Keluarga Berencana Nasional BKKBN Provinsi Jawa Barat melansir data ada tiga masalah yang kerap dialami oleh remaja yaitu penyalahgunaan NAPZA, pernikahan dini dan seks bebas. perilaku seks bebas sangat rentan dengan resiko penyakit menular seks yang salah satunya adalah HIV/AIDS.

HIV adalah singkatan dari (human immunodeficiency virus) adalah suatu virus yang dapat menyebabkan penyakit AIDS (BPS \& DEPKES, 2015). Virus ini menyerang sistem kekebalan tubuh atau imunitas tubuh sehingga tubuh menjadi lemah melawan infeksi. Dengan kata lain, kehadiran virus ini akan menyebabkan kekurangan sistem imun. 
AIDS adalah singkatan dari acquired immuno deficiency syndrome atau sindrom runtuhnya kekebalan tubuh adalah kumpulan gejala akibat menurunnya sistem kekebalan tubuh yang terjadi karena terinfeksi virus HIV (BPS \& DEPKES, 2015) akibat dari penurunan kekebalan tubuh adalah seseorang yang sangat mudah terkena berbagai penyakit infeksi yang sering berakibat fatal.

Berdasarkan data yang diperoleh dari direktorat jendral Pencegahan dan Pengendalian Penyakit Kementrian Kesehatan Republik Indonesia jumlah kumulatif kasus HIV/AIDS di Indonesia sampai agustus 2019 mencapai 4.66.859 yang teridiri atas 349.882 kasus HIV dan 116977 kasus AIDS.

Menurut data yang diperoleh dari Dinas Kesehatan Provinsi Jawa Barat per juni 2019, Jawa Barat menempati peringkat ke 4 di indonesia yang memiliki kasus HIV tertinggi. Data yang diperoleh dari Dinas Kesehatan Provinsi Jawa Barat, kasus HIV mencapai 40.276 kasus dan AIDS mencapai 10.370 kasus. Dari 27 kabupaten/kota di Jawa Barat, Kota Bandung menjadi kota dengan kasus HIV/AIDS tertinggi di Jawa barat.

Menurut kepala Dinas Kesehatan Provinsi Jawa Barat pertambahan kasus HIV/AIDS tidak hanya terjadi dalam penemuan kasus yang terdapat pada kelompok beresiko tinggi, tetapi juga sudah masuk dalam populasi beresiko rendah seperti yang ditemukan dalam kasus pada ibu rumah tangga dan anak remaja. Peningkatan kasus HIV/AIDS paling signifikan dialami oleh ibu rumah tangga baru setelahnya adalah kalangan remaja yaitu pelajar mahasiswa.

Menurut laporan UNAIDS (2014) menyebutkan bahwa hampir setengah dari seluruh penderita HIV baru di dunia adalah orang muda dengan usia 19-24 tahun.
Sementara itu, UNAIDS (2016) mencatatat bahwa remaja usia 15-24 tahun beresiko tinggi untuk terinfeksi HIV. Pada tahun 2015, secara global terhitung sebesar $20 \%$ terjadi infeksi baru pada remaja perempuan dan $14 \%$ remaja laki-laki.

Menurut komisi penanggulangan AIDS Nasional Kelompok remaja sangat beresiko tertular HIV, akan tetapi remaja sendiri merupakan sebuah jendela kesempatan untuk mewujudkan generasi terbebas HIV/AIDS. dengan demikian, diperlukan strategi termasuk penguatan aspek-aspek yang akan melindungi remaja dari berbagai kerentanan infeksi HIV sejak dini sebagai upaya pencegahan.

Salah satu faktor personal yang berpengaruh terhadap munculnya perilaku menyimpang atau beresiko bagi remaja adalah efikasi diri. Efikasi diri merupakan suatu keyakinan atau kepercayaan diri individu mengenai kemampuannya untuk mengorganisasi, melakukan suatu tugas, mencapai suatu tujuan menghasilkan sesuatu dan mengimplementasi tindakan untuk mencapai kecakapan tertentu. Menurut Bandura Efikasi diri mengacu pada kepercayaan individu akan kemampuannya untuk sukses dalam melakukan sesuatu.

Efikasi diri adalah sebuah keyakinan tentang probabilitas bahwa seseorang dapat melaksanakan dengan sukses beberapa tindakan atau masa depan dan mencapai beberapa hasil (Fauziah \& Syahputra, 2019) Efikasi diri dapat diartikan sebagai persepsi pribadi dari seseorang untuk meyakini kemampuan diirnya dalam melakukan perilkau yang diyakini akan mendapat hasil yang sukses. Pada konteks HIV/AIDS, efikasi diri pencegahan perilaku beresiko didefinsikan sebagai keyakinan individu untuk berhasil dalam pencegahan pada perilaku beresiko 
HIV/AIDS dan tidak terlibat dalam perilaku beresiko HIV/AIDS.

Pencegahan terhadap infeksi HIV/AIDS pada kalangan remaja dapat dilakukan dengan mengembangkan berbagai program atau intevensi melalui penguatan efikasi diri remaja dalam mencegah perilaku seksual beresiko. (luszczynska, Aleksandra, Guttiereze-Dona, Benicio\&Schwarzer, \& Raif, 2005).

Upaya yang dapat dilakukan dalam pencegahan perilaku beresiko pada remaja melalui penguatan efikasi diri, menurut hasil penelitian yang dilakukan oleh (Lee, Yi-Hui, Salman, Patrick, \& J., 2009) yang meneliti mengenai hubungan efikasi diri, gejala depresi dan perilaku seksual beresiko.remaja yang tidak memiliki depresi akan memiliki efikasi diri pencegahan HIV/AIDS yang tinggi. Hal tersebut diperkuat dengan penelitian yang dilakukan oleh (Givaudan, et al., 2007) bahwa program untuk meningkatkan pencegahan terhadap infeksi HIV/AIDS pada remaja dapat dilakukan melalui pengembangan efikasi diri. Dengan demikian menejemen efikasi diri yang tepat dalam pencegahan HIV/AIDS pada remaja dapat mengurangi resiko terjadinya infeksi HIV/AIDS pada remaja.

Berdasarkan uraian permasalahan serta latar belakang diatas, maka peneliti tertarik melakukan penelitian dengan judul "efikasi diri remaja dalam mencegahan perilaku beresiko HIV/AIDS di Kota Bandung”

\section{METODE}

Desain penelitian yangdigunakan dalam penelitian ini yaitu metode deskriptif pendekatan kuantitatif dimana bertujuan untuk memperoleh gambaran secara empiris bagaiamana efikasi diri remaja dalam mencegah perilaku beresiko HIV/AIDS di Kota
Bandung. Populasi dalam penelitian yaitu remaja di kota bandung yang berusia 15-18 tahun. Teknik sampling yang digunakan yaitu accidental sampling dan didapatkan responden sebanyak 144. Alat ukur yang digunakan dalam penelitian ini yaitu menggunakan skala likert dan skala guttman. Uji validitas menggunakan validitas muka dalam pembuatan kisi-kisi dan instrument penelitian serta validitas statistic menggunakan SPSS versi 22 dengan signifikasi sebesar 5\% (nilai $\mathrm{R}$ hitung sebesar 0,367). Uji realibilitas digunakan dengan bantuan SPSS versi 22 IBM alpha croanbach dan didapatkan hasil sebesar 0,893 pada skala likert dan 0,71 pada skala guttman. Teknik pengumpulan data menggunakan kuesioner dengan bantuan media google formulir. Analisis data menggunakan statistic deskriptif.

\section{HASIL}

Kota Bandung terletak di wilayah Jawa Barat dan merupakan Ibukota Propinsi Jawa Barat. Kota Bandung secara geografis terletak antara $107^{\circ}$ bujur timur dan $6^{\circ} 55^{\prime}$ lintang selatan dan secara administratif terdiri dari 26 kecamatan. Kota ini dikelilingi oleh kabupaten Bandung dan terletak pada lokasi yang strategis dilihat dari segi komunikasi, perekonomian maupun keamanan serta dikelilingi oleh gunung sehingga terhindar dari bencana tsunami namun terancam melalui gunung yang banyak khususnya tangkuban perahu yang merupakan salah satu gunung di jawa barat yang masih aktif.

Posisinya pada poros jalan raya barattimur yang memudahkan hubungan dengan ibukota Jakarta, dan utara-selatan yang memudahkan akses ke daerah perkebunan di Subang dan Pengalengan, letaknya yang tidak terisolasi, dan jalur komunikasinya baik dan 
Iklim kota ini merupakan iklim pegunungan yang lembab dan sejuk. Untuk mengetahui gambaran demografi warga Kota Bandung lebih jelas dapat dirincikan melalui tabel jumlah penduduk berdasarkan golongan umur, jenis kelamin dan tingkat pendidikan.

Tabel 1 Jumlah penduduk berdasarkan

usia dan jenis kelamin di kota bandung tahun 2020

\begin{tabular}{|c|c|c|c|}
\hline \multirow{2}{*}{$\begin{array}{c}\text { Kelom } \\
\text { pok } \\
\text { usia }\end{array}$} & \multicolumn{3}{|c|}{ Penduduk kota bandung } \\
\hline & Laki-Laki & $\begin{array}{c}\text { Perempu } \\
\text { an }\end{array}$ & Total \\
\hline $0-4$ & 100268 & 96262 & 196530 \\
\hline $5-9$ & 97256 & 92702 & 189958 \\
\hline $10-14$ & 86810 & 83316 & 170126 \\
\hline $15-19$ & 106374 & 108412 & 214786 \\
\hline $20-24$ & 132224 & 123500 & 255724 \\
\hline $25-29$ & 117650 & 108690 & 226340 \\
\hline $30-34$ & 108335 & 99937 & 208272 \\
\hline $35-39$ & 97014 & 95903 & 192917 \\
\hline $40-44$ & 93112 & 94070 & 187182 \\
\hline $45-49$ & 83849 & 86414 & 170263 \\
\hline $50-54$ & 74627 & 75902 & 150529 \\
\hline $55-59$ & 60992 & 63231 & 124223 \\
\hline $60-64$ & 41950 & 41629 & 83579 \\
\hline $65-69$ & 29764 & 30654 & 60418 \\
\hline $70-74$ & 18006 & 19263 & 37269 \\
\hline $75+$ & 15685 & 24087 & 39772 \\
\hline Jumlah & 1.263 .916 & 1.243 .972 & 2.507 .888 \\
\hline
\end{tabular}

Sumber:Badan Pusat Statisti Kota

Bandung tahun 2020
Tabel 1 menunjukkan bahwa penduduk kota bandung mayoritas berada pada rentang usia 20-24 tahun dengan total 255.742 jiwa. Rentang usia 25-29 tahun menjadi peringkat kedua dengan total; 226.340 jiwa. Berdasarkan tabel 4.1 dapat disimpulkan bahwa jumlah penduduk kota bandung berdasarkan jenis kelamin laki-laki dan perempuan hampir berimbang dengan jumlah penduduk laki laki sebanyak 1.263.916 jiwa dam perempuan sebanyak 1.243.972 jiwa. Jumlah remaja di kota bandung usia 15-19 tahun berada pada peringkat ke tiga dengan total penduduk sebanyak 214786.

Epidemi HIV/AIDS menjadi masalah di kota bandung yang merupakan provinsi urutan ke-4 paling beresiko HIV/AIDS di Indonesia (Kemenkes RI, 2020). Jumlah kasus HIV/AIDS dikota bandung per maret 2020 mencapai 49.440 kasus dengan 41.878 kasus HIVdan 7562 kasus AIDS. berikut adalah data persebaran HIV/AIDS menurut usia dikota bandung.

Tabel 2 Data Persebaran HIV/AIDS Di Kota Bandung Tahun 2020

\begin{tabular}{|c|c|c|c|}
\hline \multirow[t]{2}{*}{$\begin{array}{l}\mathbf{N} \\
\mathbf{0}\end{array}$} & \multirow[t]{2}{*}{$\begin{array}{l}\text { Rentan } \\
\text { Usia }\end{array}$} & \multicolumn{2}{|c|}{$\begin{array}{c}\text { Jumlah Pengidap di } \\
\text { Kota Bandung }\end{array}$} \\
\hline & & HIV & AIDS \\
\hline 1 & $0-4$ & 3 & 17 \\
\hline 2 & 4-14 & 2 & 12 \\
\hline 3 & $15-19$ & 7 & $\overline{46}$ \\
\hline 4 & $20-49$ & 315 & 1991 \\
\hline 5 & $50>$ & 30 & 195 \\
\hline & Jumlah & 387 & 2261 \\
\hline
\end{tabular}

Menurut tabel 2 tersebut jumlah yang terkonfirmasi HIV/AIDS di kota bandung mencapai 383 kasus HIV dan 2261 kasus AIDS. Kasus terbanyak pada rentan usia 20-49 tahun dengan jumlah kasus HIV sebanyak 315 dan kasus AIDS sebanyak 1991. Remaja usia 
15-19 tahun menduduki peringkat ke-3 sebanyak total kasus 53 kasus HIV/AIDS.

1. Karakteristik responden dan tingkat efikasi diri berdasarkan usia

Responden penelitian terdiri dari berbagai rentan usia yaitu 15 sampai dengan 18 tahun. Adapun data responden penelitian berdasarkan usia dapat dilihat pada tabel berikut:

Tabel 3 karakteristik responden berdasarkan usia

\begin{tabular}{|l|l|r|r|}
\hline No & Usia & Frekuensi & $\begin{array}{c}\text { Persentase } \\
(\%)\end{array}$ \\
\hline 1 & 15 & 15 & 10,42 \\
\hline 2 & 16 & 53 & 36,81 \\
\hline 3 & 17 & 47 & 32,64 \\
\hline 4 & 18 & 29 & 20,13 \\
\hline \multicolumn{2}{|l|}{ Total } & 144 & 100 \\
\hline
\end{tabular}

Berdasarkan tabel 3 dapat digambarkan bahwa responden terbanyak yaitu dari usia 16 tahun yaitu sebanyak 53 jiwa dengan persentase $36,81 \%$ selanjutnya pada usia 17 tahun sebanyak 47 jiwa dengan persentase $32,64 \%$, pada urutan ketiga pada usia 18 tahun yaitu sebanyak 29 jiwa dengan persentase $20,13 \%$ dan terakhir pada usia 15 tahun sebanyak 15 jiwa dengan persentase $10,42 \%$.

Berikut adalah tingkat efikasi diri remaja yang dilihat dari persebaran jawaban responden pada setiap kategori usia:
Tabel 4 tingkat efikasi diri jawaban responden pada karakteristik usia

\begin{tabular}{|l|r|c|c|c|}
\hline $\begin{array}{l}\text { Kategori } \\
\text { usia/ } \\
\begin{array}{l}\text { Tingkat } \\
\text { efikasi } \\
\text { diri }\end{array}\end{array}$ & $\begin{array}{c}\mathbf{1 5} \\
\text { tahun } \\
(\%)\end{array}$ & $\begin{array}{c}\mathbf{1 6} \\
\text { tahun } \\
(\%)\end{array}$ & $\begin{array}{c}\mathbf{1 7} \\
\text { tahun } \\
(\%)\end{array}$ & $\begin{array}{c}\mathbf{1 8} \\
\text { tahun } \\
(\%)\end{array}$ \\
\hline Rendah & 0 & 15,09 & 17,03 & 24,13 \\
\hline Sedang & 86,66 & 69,82 & 68,08 & 72,41 \\
\hline Tingi & 13,34 & 15,09 & 14,89 & 3,46 \\
\hline
\end{tabular}

Berdasarkan tabel 4 diketahui bahwa efikasi diri terendah dimiliki oleh responden usia 18 tahun sebesar 24,13\%, sedangkan efikasi diri sedang yaitu pada usia 15 tahun sebesar $86,66 \%$ serta efikasi diri tinggi dimiliki oleh usia 16 tahun sebesar 15,09\%. Hal ini menggambarkan bahwa remaja usia 18 tahun yang memiliki efikasi diri yang cukup rendah dalam usaha mencegah perilaku beresiko HIV/AIDS.

2. Karakteristik responden dan tingkat efikasi diri berdasarkan jenis kelamin

Data karakteristik responden pada penelitian berdasarkan jenis kelamin dapat dilihat pada tabel berikut ini:

Tabel 5 karakteristik responden berdasarkan jenis kelamin

\begin{tabular}{|l|c|r|r|}
\hline $\begin{array}{l}\text { N } \\
\mathbf{0}\end{array}$ & $\begin{array}{c}\text { Jenis } \\
\text { kelamin }\end{array}$ & $\begin{array}{c}\text { Frekue } \\
\text { nsi }\end{array}$ & $\begin{array}{c}\text { Persent } \\
\text { ase } \\
(\%)\end{array}$ \\
\hline 1 & Laki- laki & 39 & 27,08 \\
\hline 2 & Perempuan & 105 & 72,92 \\
\hline \multicolumn{2}{r|}{ Total } & 144 & 100 \\
\hline
\end{tabular}

Berdasarkan tabel 5 dapat digambarkan bahwa responden penelitian yang berjenis kelamin perempuan jauh lebih 
banyak dibandingkan dengan laki-laki. Jumlah responden laki laki sebanyak 39 jiwa dengan persentase $27,08 \%$ sedangkan jumlah responden penelitian perempuan sebanyak 105 jiwa dengan persentase $72,92 \%$. Hal ini menggambarkan bahwa jumlah responden pada penelitian ini didominasi oleh responden perempuan.

Berikut adalah tingkat efikasi diri remaja yang dilihat dari persebaran jawaban responden pada setiap kategori jenis kelamin:

Tabel 6 Tingkat Efikasi Diri Jawaban Responden pada Karakteristik Jenis Kelamin

\begin{tabular}{|l|r|r|}
\hline $\begin{array}{l}\text { Kategori } \\
\text { usia/ } \\
\text { Tingkat } \\
\text { efikasi diri }\end{array}$ & $\begin{array}{c}\text { Laki-laki } \\
(\boldsymbol{\%})\end{array}$ & $\begin{array}{c}\text { perempuan } \\
(\boldsymbol{\%})\end{array}$ \\
\hline Rendah & 33,33 & 9,52 \\
\hline Sedang & 66,64 & 73,34 \\
\hline Tingi & 0 & 17,14 \\
\hline
\end{tabular}

Berdasarkan tabel 6 diketahui bahwa efikasi diri terendah dimiliki oleh responden laki-laki sebesar 33,33\%, sedangkan efikasi diri sedang yaitu pada perempuan sebesar $73,34 \%$ serta efikasi diri tinggi dimiliki oleh perempuan sebesar $17,14 \%$. Hal ini menggambarkan bahwa remaja laki-laki lebih memiliki efikasi diri yang cukup rendah dibandingkan dengan perempuan dalam usaha mencegah perilaku beresiko HIV/AIDS.

3. Karakteristik responden dan tingkat efikasi diri berdasarkan pendidikan

Responden penelitian memiliki beberapa tingkatan pendidikan yang sedang ditempuh menyesuaikan usia yang menjadi sasaran penelitian 15-18 tahun. Uraian karakteristik responden berdasarkan tingkat pendidikan yaitu sebagai berikut: $\begin{array}{llll}\text { Tabel } & 7 & \text { karakteristik } & \text { pendidikan }\end{array}$ berdasarkan pendidikan

\begin{tabular}{|c|c|c|c|}
\hline No & Pendidikan & Frekuensi & $\begin{array}{c}\text { Persentase } \\
(\%)\end{array}$ \\
\hline 1 & SMP & 3 & 2,08 \\
\hline 2 & SMA/SMK & 124 & 86,11 \\
\hline 3 & $\begin{array}{l}\text { Perguruan } \\
\text { Tinggi }\end{array}$ & 14 & 9,73 \\
\hline 4 & Dll & 3 & 2,08 \\
\hline & Total & 144 & 100 \\
\hline
\end{tabular}

Berdasarkan tabel 7 dapat digambarkan bahwa sebagian besar responden penelitian berasal dari kalangan pelajar SMA/SMK sebanyak 124 jiwa dengan persentase $86,11 \%$ selanjutnya yaitu kalangan mahasiswa sebanyak 14 jiwa dengan persentase 9,73\% serta diurutan selanjutnya yaitu pada tingkat pendidikan SMP dan lainnya masing masing sebanyak 3 jiwa dengan persentase 2,08\%.

Berikut adalah tingkat efikasi diri remaja yang dilihat dari persebaran jawaban responden pada setiap kategori pendidikan:

Tabel 8 tingkat efikasi diri jawaban responden pada karakteristik pendidikan

\begin{tabular}{|l|r|r|r|r|}
\hline $\begin{array}{l}\text { Kategori } \\
\text { usia/ } \\
\begin{array}{l}\text { Tingkat } \\
\text { efikasi diri }\end{array}\end{array}$ & $\begin{array}{r}\text { SMP } \\
(\boldsymbol{\%})\end{array}$ & $\begin{array}{c}\text { SMA/ } \\
\text { SMK } \\
(\boldsymbol{\%})\end{array}$ & $\begin{array}{c}\text { PT } \\
(\boldsymbol{\%})\end{array}$ & $\begin{array}{c}\text { DLL } \\
(\boldsymbol{\%})\end{array}$ \\
\hline Rendah & 0 & 12,90 & 0 & 66,66 \\
\hline Sedang & $100 \%$ & 71,77 & 78,58 & 33,34 \\
\hline Tingi & 0 & 15,33 & 21,42 & 0 \\
\hline
\end{tabular}

Berdasarkan tabel 8 diketahui bahwa efikasi diri terendah dimiliki oleh responden SMA sebesar $12,90 \%$, sedangkan efikasi diri sedang yaitu pada SMP sebesar $100 \%$ serta efikasi diri tinggi dimiliki oleh perguruan tinggi atau mahasiswa sebesar 21,42\%. Hal ini menggambarkan bahwa remaja mahasiswa 
yang memiliki efikasi diri yang cukup tinggi dalam usaha mencegah perilaku beresiko HIV/AIDS.

Berikut adalah hasil penelitian mengenai efikasi diri remaja dalam mencegah perilaku beresiko

\section{Kognitif remaja dalam mencegah} perilaku beresiko HIV/AIDS

\section{a. Dimensi Pengetahuan}

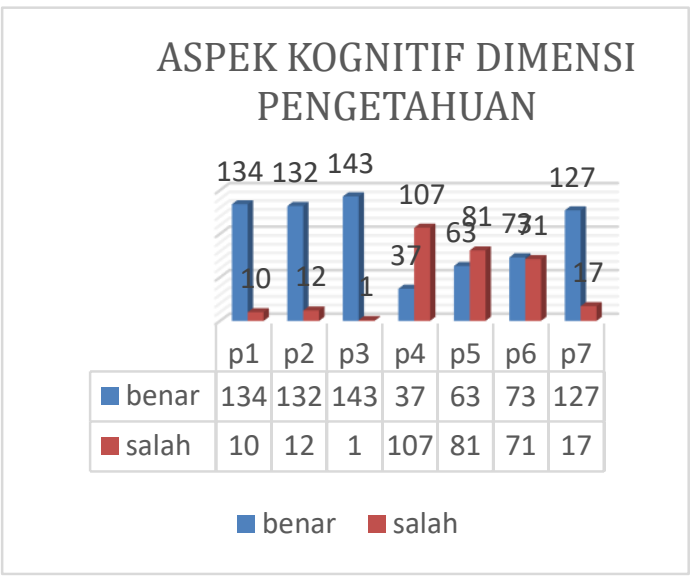

Diagram 1: dimensi pengetahuan

Diagram diatas adalah gambaran secara keeseluruhan mengenai jawaban dari setiap responden untuk dimensi pengentahuan pada aspke kognitif. Dari setiap item pernyataan remaja memiliki kemampuan yang cukup tinggi dalam dimensi ini terlihat dari total menjawab benar pada setiap pernyataan. Dari 7 item pernyataan ada dua pernyataan yang cukup banyak dijawab salah oleh responden yaitu item pernyataan seperti pernyataan "Menonton vidio pornografi adalah salah satu perilaku yang beresiko menyebabkan HIV/AIDS" serta "Berbicara mengenai hubungan seksual dengan pasangan adalah salah satu hal penting dalam menjalin hubungan" responden lebih banyak menjawab pernyataan yang salah dibandingkan dengan jawaban yang benar.

\section{b. Dimensi pengalaman mencegah}

ASPEK KOGNITIF DIMENSI PENGALAMAN MENCEGAH

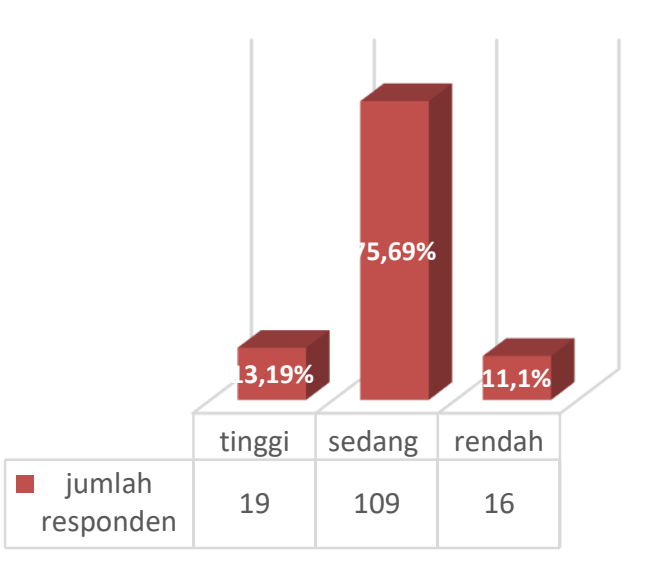

\section{Diagram 2:dimensi pengalaman mencegah}

Diagram 2 diagram aspek kognitif dimensi pengalaman mencegah pada efikasi diri remaja dalam mencegah perilaku beresiko hiv/aids di kota bandung berdasarkan jawaban responenden. Kategori kelas pada dimensi pengalaman mencegah dibagi menjadi tiga kelas yaitu tinggi sedang dan rendah. Kelas interval tinggi berjumlah 19 orang atau 13,19\% kelas interval sedang sebanyak 109 responden atau $75,69 \%$ dan kelas interval rendah sabanyak 16 orang atau $11,1 \%$. Perolehan mayoritas responden pada kelas interval sedang. Peneliti mengambil asumsi bahwa dalam pengalaman mencegah remaja memiliki kemampuan yang tidak terlalu tinggi namun pada kelas sedang 
2. Motivasi remaja dalam mencegah perilaku beresiko HIV/AIDS

a. Dorongan intenal

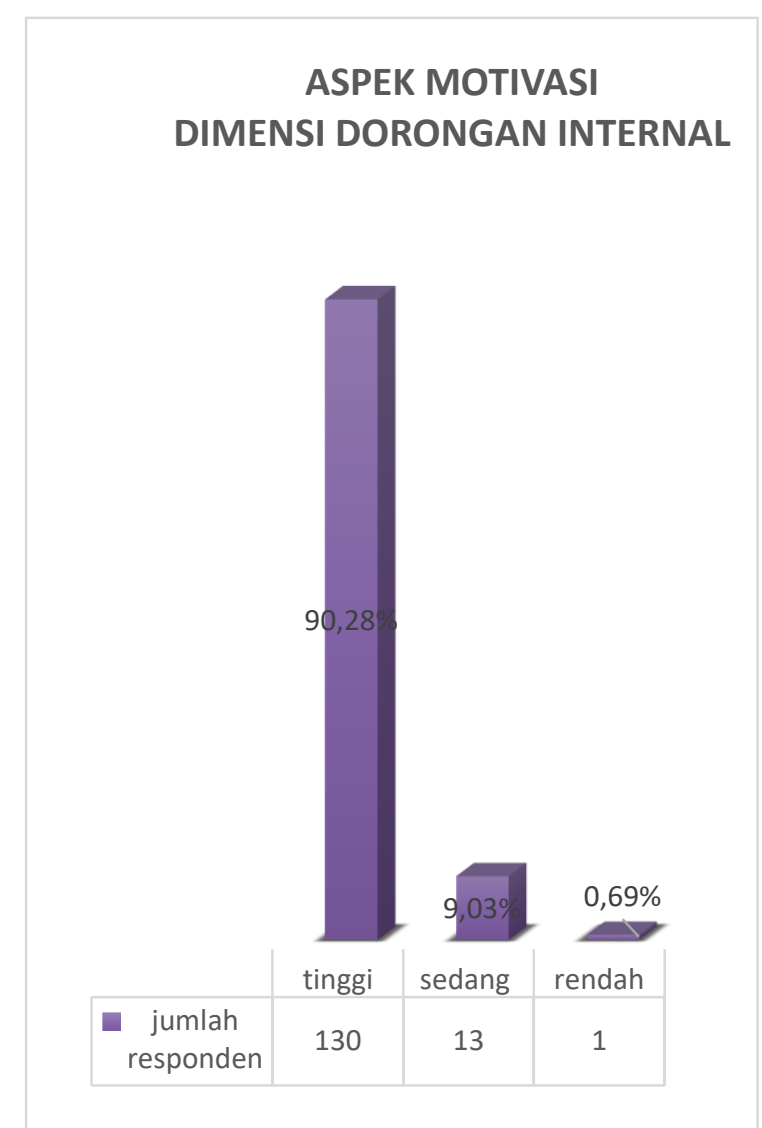

Diagram 3: dimensi dorongan internal

Diagram aspek motivasi dimensi dorongan internal efikasidiri remaja dalam mencegah perilaku beresiko HIV/AIDS di kota bandung berdasarkan jawaban responden. Kategiri kelas pada dimensi dorongan internal dibagi kedalam tiga kelas yaitu tinggi, sedang dan rendah. Kelas interval tinggi berjumlah 130 atau $90,28 \%$ pada kelas interval sedang sebanyak 13 responden atau $9,03 \%$ dan pada kelas interval rendah sebanyak 1 responden atau sebanyak $0,69 \%$.

Perolehan mayoritas responden berada pada interval tinggi, peneliti mengambil asumsi bahwa respoden memiliki dorongan interval yang baik dan tinggi dalam efikasi diri mencegah perilaku beresiko HIV/AIDS

\section{b.Dorongan eksternal}

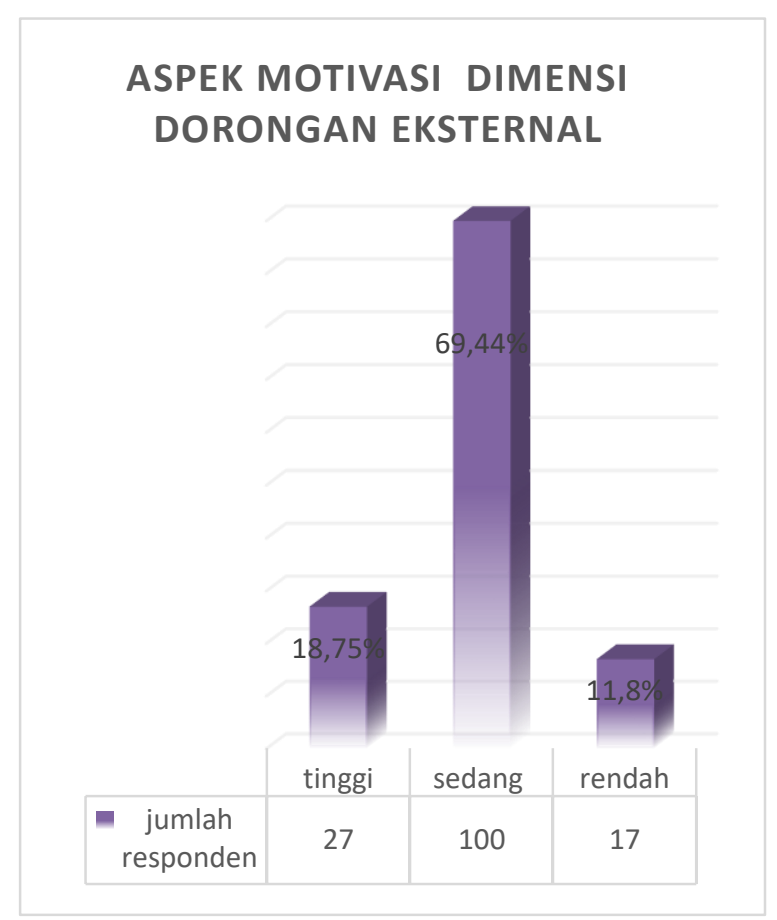

Diagram 4: dimensi dorongan eksternal

Diagram aspek motivasi dimensi dorongan eksternal efikasi diri remaja dalam mencegah perilaku beresiko hiv/aids dikota bandung berdasarkan jawaban responden. Kategori kelas pada dimensi dorongan internal dibagi menjadi tiga kelas yaitu tinggi sedang dan rendah. Kelas interval tinggi berjumlah 27 atau $18,75 \%$ kelas interval sedang sebanyak 100 responden atau $69,44 \%$ dan kelas interval rendah sebanyak 17 responden atau $11,08 \%$.

Perolehan mayoritas responden berada pada kelas interval sedang peneliti mengambil asumsi bahwa dorongan eksternal atau dorongan yang ada diluar diri remaja dalam efikasi diri pencegahan perilaku beresiko tidak terlalu tinggi. 
3. Afeksi remaja dalam mencegah perilaku beresiko HIV/AIDS

a. Pengendalian emosi

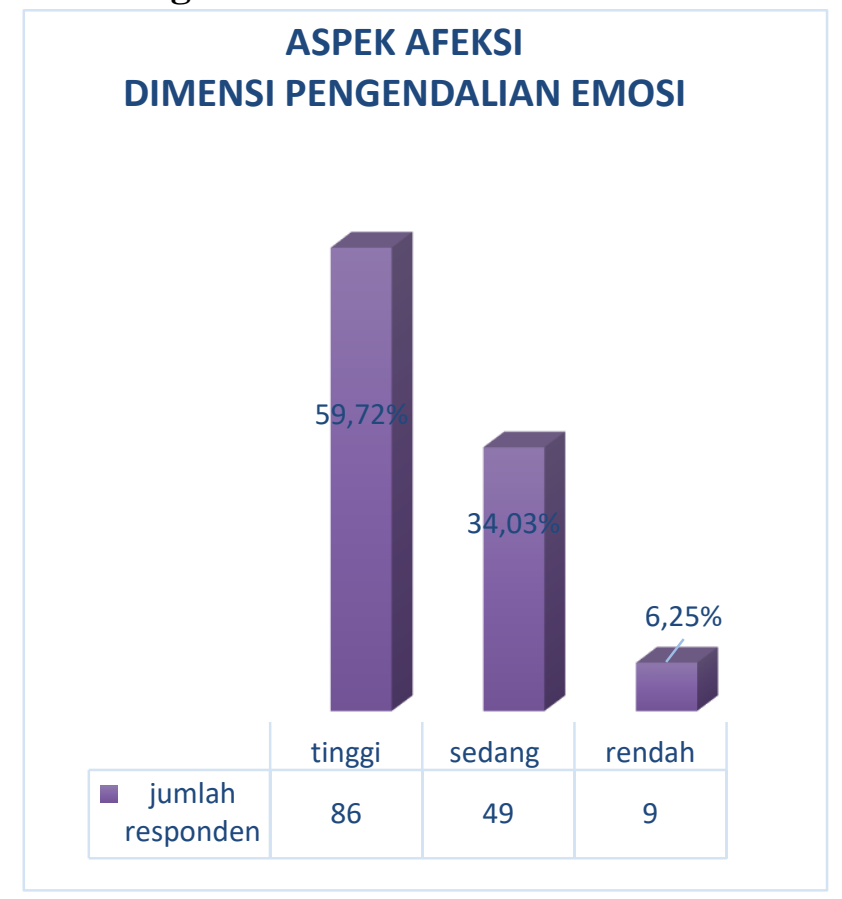

\section{Diagram 5 dimensi pengendalian emosi}

Aspek afeksi dimensi pengendalian emosi pada efikasi diri remaja dalam mencegah perilaku beresiko HIV/AIDS di kota bandung berdasarkan jawaban responden. Kategori kelas pada dimensi pengendalian emosi dibagi menjadi tiga yaitu tinggi,sedang dan rendah. Kelas interval tinggi berjumlah 86 responden atau $59,72 \%$ kelas interval sedang berjumlah 49 responden atau $34,03 \%$ dan kelas interval rendah berjumlah 9 responden dengan $6,25 \%$. Perolehan mayoritas responden pada kategori tinggi sebanyak 69 dan sedang 64 responden peneliti dapat mengambil asumsi bahwa remaja dalam dimensi pengendalian cukup tinggi dalam mencegah perilaku beresiko HIV/AIDS.

\section{b. Mengatasi stress}

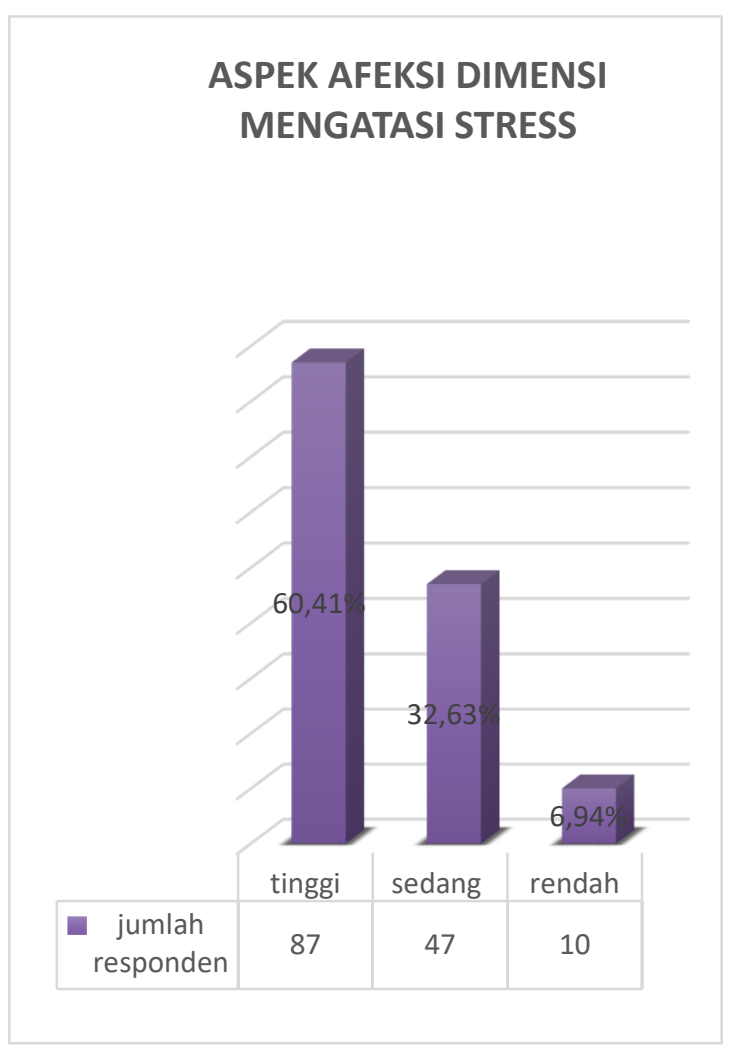

\section{Diagram 6: dimensi mengatasi stress}

Aspek afeksi dimensi mengatasi stress efikasi diri remaja dalam mencegah perilaku beresiko HIV/AIDS dikota bandung berdasarkan jawaban responden. Kategori kelas pada dimensi mengatasi stress dibagi menjadi tiga kelas yaitu tinggi, sedang dan rendah. Kelas interval tinggi berjumlah 87 responden atau $60,41 \%$, kelas interval sedang sebanyak 47 responden atau $32,63 \%$ dan kelas interval rendah sebanyak 10 responden atau $6,94 \%$. Perolehan mayoritas responden berada pada kelas interval tinggi. Peneliti dapat mengambil asumsi bahwa kemampuan remaja dalam efikasi diri mencegah perlaku beresiko HIV/AIDS dalam dimensi mengatasi stress kategori tinggi. 
4. Seleksi remaja dalam mencegah perilaku beresiko HIV/AIDS

a. Selektif

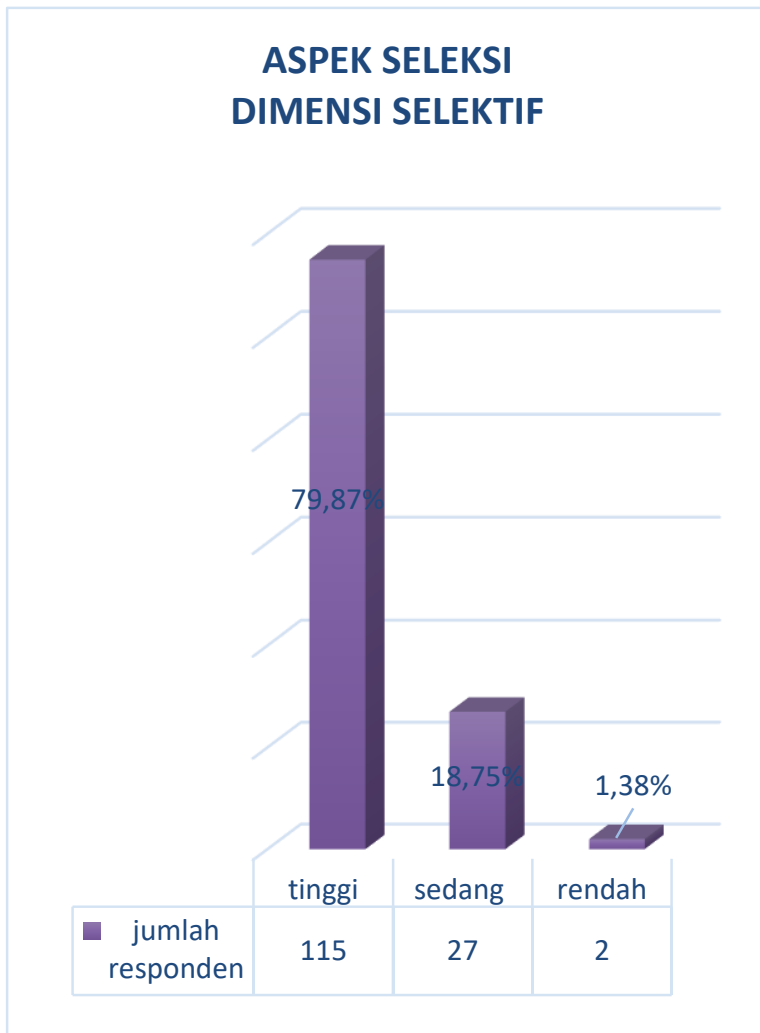

Diagram 7 : dimensi selektif

Aspek seleksi dimensi selektif efikasi diri remaja dalam mencegah perilaku beresiko HIV/AIDS dikota bandung berdasarkan jawaban responden. Kategori kelas pada dimensi selektif dibagi menjadi tiga kelas yaitu tinggi, sedang dan rendag. Kelas interval tinggi berjumalah 115 responden atau $79,87 \%$, kelas interval sedang berjumlah 27 atau $18,75 \%$ dan kelas interval rendah berjumlah 2 atau $1,38 \%$. Perolehan mayoritas responden berada pada kelas interval tinggi peneliti dapat mengambil asumsi bahwa efikasi diri remaja dalam dimensi selektif yaitu tinggi.

\section{b. Ketegasan}

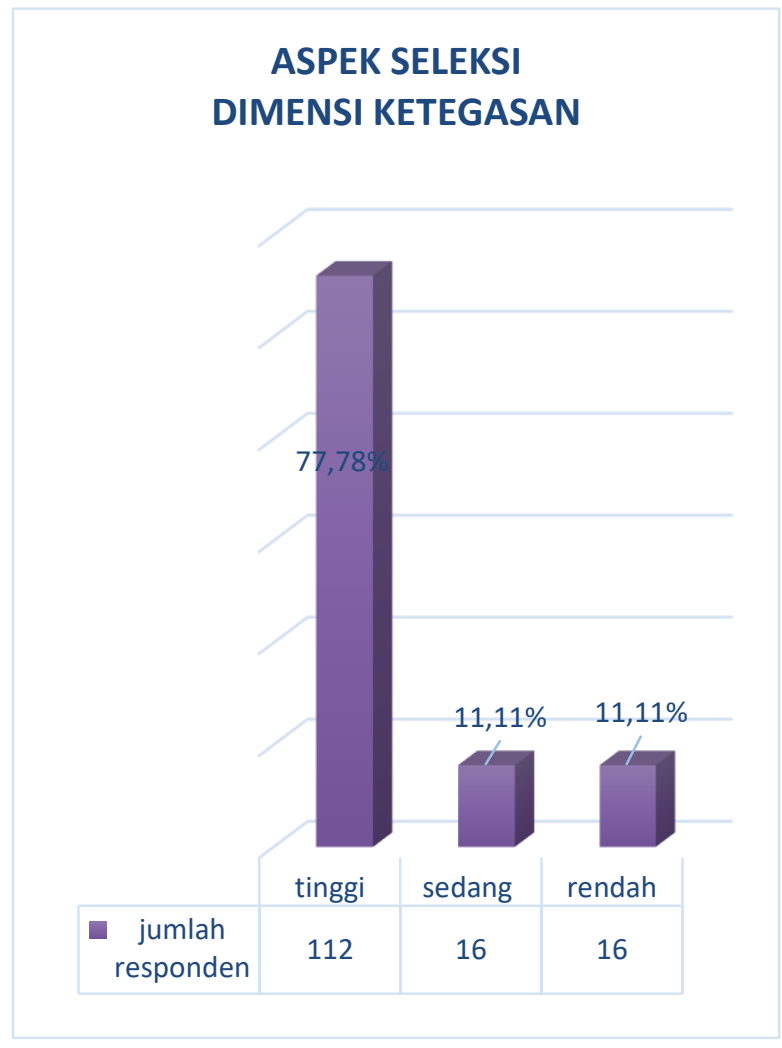

\section{Diagram 8 dimensi ketegasan}

Aspek seleksi dimensi ketegasan efikasi diri remaja dalam mencegah perilaku beresiko HIV/AIDS dikota bandung berdasarkan jawaban responden. Kategori kelas pada dimensi ketegasan dibagi menjadi tiga kelas yaitu tinggi, sedang dan rendah. Kelas interval tinggi berjumalah 112 responden atau $77,78 \%$, kelas interval sedang berjumlah 16 atau $11,11 \%$ dan kelas interval rendah berjumlah 16 atau 11,11\%. Perolehan mayoritas responden berada pada kelas interval tinggi peneliti dapat mengambil asumsi bahwa efikasi diri remaja dalam dimensi ketegasan yaitu tinggi. 
Gambaran efikasi diri remaja secara keseluruhan aspek

\section{EFIKASI DIRI REMAJA KESELURUHAN ASPEK}

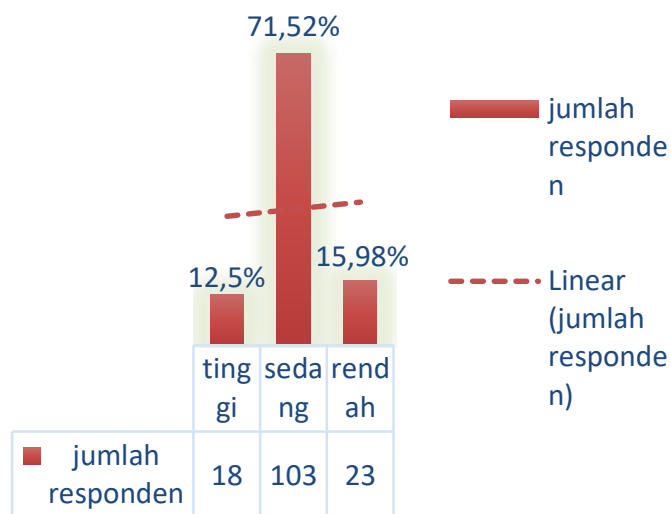

\section{Diagram 9: efikasi diri keseluruhan aspek}

Diagram 4.9 keseluruhan aspek efikasi diri remaja dalam mencegah perilaku beresiko HIV/AIDS dikota bandung berdasarkan jawaban responden. Kategori kelas dibagi menjadi tiga kelas yaitu tinggi, sedang dan rendah. Kelas interval tinggi berjumalah 18 responden atau $12,50 \%$ kelas interval sedang berjumlah 103 atau 71,52\%, dan kelas interval rendah berjumlah 23 atau $15,98 \%$. Perolehan mayoritas responden berada pada kelas interval sedang peneliti dapat mengambil asumsi bahwa efikasi diri remaja dalam keseluruhan aspek yaitu tidak terlalu tinggi.

\section{PEMBAHASAN}

Efikasi diri atau keyakinan diri merupakan salah satu hal terpenting yang akan memperngaruhi bagaimana remaja dalam usaha untuk mencegah perilaku beresiko HIV/AIDS. efikasi diri merupakan pondasi awal dimana seseorang sedang melakukan suatu tugas ataupun mencapai suatu tujuan yang ingin dicapai. Dengan memuliki efikasi diri seseorang akan mampu memahami dan berpikir, memiliki dorongan yang tinggi mampu mengontrol emosi yang dimilikinya serta dapat dengan bijak memilih tindakan tindakan mana yang harus dilakukan agar dapat mencapai tujuannya.

Berdasarkan hasil penelitian efikasi diri remaja dalam mencegah perilaku beresiko HIV/AIDS di kota bandung, peneliti mendapatkan hasil bahwa efikasi diri remaja dalam mencegah perilaku beresiko HIV/AIDS dalam kategori sedang. Hal tersebut dapat dikatakan bahwa responden rentan untuk efikasi atau memiliki keyakinan diri yang akan menghambat remaja dalam pencegahan perilaku beresiko HIV/AIDS. sementara itu untuk mengetahui penyebab mengapa hasil dari penelitian ini termasuk kedalam kategori yang sedang peneliti akan merekap kembali hasil dari penelitian ini dari setiap aspek dan dimensi sehingga nantinya akan diketahui hal apa yang harus ditanggulangi dan ditangani agar efikasi diri remaja dapat meningkat. Berikut adalah rekapitulasi perolehan kategori pada aspek efikasi diri sebagai berikut:

Tabel 9 kategori hasil aspek efikasi diri remaja dalam mencegah perilaku beresiko HIV/AIDS

\begin{tabular}{|c|c|c|c|c|}
\hline $\begin{array}{l}\mathbf{N} \\
\mathbf{O}\end{array}$ & Aspek & Dimensi & Kategori & $\begin{array}{c}\text { Persenta } \\
\text { se }(\%)\end{array}$ \\
\hline \multirow[t]{6}{*}{1} & \multirow[t]{6}{*}{ Kognitif } & \multirow{3}{*}{$\begin{array}{c}\text { Pengetahu } \\
\text { an }\end{array}$} & Tinggi & 68,75 \\
\hline & & & Sedang & 31,25 \\
\hline & & & Rendah & 0 \\
\hline & & \multirow{3}{*}{$\begin{array}{c}\text { Pengalama } \\
\mathrm{n} \\
\text { mencegah }\end{array}$} & Tinggi & 13,19 \\
\hline & & & Sedang & 75,69 \\
\hline & & & Rendah & 11,10 \\
\hline \multirow[t]{6}{*}{2} & \multirow{6}{*}{$\begin{array}{c}\text { Motivas } \\
\text { i }\end{array}$} & \multirow{3}{*}{$\begin{array}{c}\text { Dorongan } \\
\text { internal }\end{array}$} & Tinggi & 90,28 \\
\hline & & & Sedang & 9,03 \\
\hline & & & Rendah & 0,69 \\
\hline & & \multirow{3}{*}{$\begin{array}{l}\text { Dorongan } \\
\text { eksternal }\end{array}$} & Tinggi & 18,75 \\
\hline & & & Sedang & 64,44 \\
\hline & & & Rendah & 11,80 \\
\hline \multirow[t]{4}{*}{3} & \multirow[t]{4}{*}{ Afeksi } & \multirow{4}{*}{$\begin{array}{c}\text { Pengendali } \\
\text { an emosi }\end{array}$} & Tinggi & 59,72 \\
\hline & & & Sedang & 34,03 \\
\hline & & & Rendah & 6,25 \\
\hline & & & Tinggi & 60,41 \\
\hline
\end{tabular}




\begin{tabular}{|l|l|c|c|r|}
\hline & & Mengatasi & Sedang & 32,63 \\
\cline { 4 - 5 } & & stress & Rendah & 6,94 \\
\hline 4 & \multirow{3}{*}{ Seleksi } & Selektif & Tinggi & 79,87 \\
\cline { 4 - 5 } & & Sedang & 18,75 \\
\cline { 4 - 5 } & & Rendah & 1,38 \\
\cline { 4 - 5 } & & Ketegasan & Tinggi & 77,78 \\
\cline { 4 - 5 } & & Sedang & 11,11 \\
\cline { 4 - 5 } & & Rendah & 11,11 \\
\cline { 3 - 4 } & & & & \\
\cline { 3 - 5 } & & & &
\end{tabular}

Mengacu pada hasil penelitian dan tabel 9 dapat disimpulkan bahwa efikasi diri remaja berada pada kategori sedang. Kategori ini menunjukkan bahwa responden cukup memiliki keyakinan diri untuk dapat mencegah perilaku yang mengarah kepada HIV/AIDS, walaupun terdapat beberapa item yang memiliki skor rendah di dalam aspeknya. Beberapa aspek tersebut yang memiliki rendah karena terdapat beberapa faktor diantaranya yaitu faktor usia, jenis kelamin, serta pendidikan yang sedang ditempuh. Seperti yang dikemukakan oleh bandura bahwa efikasi diri dapat dipengaruhi oleh beberapa faktor yaitu jenis kelamin, usia, tingkat pendidikan serta pengalaman.

Merujuk pada hasil penelitian, telah didapatkan hasil mengenai skor masing masing responden di tiap-tiap aspeknya. Aspek kognitif dalam hal pengetahuan responden dinilai mampu memahami dan mengetahui mengenai pencegahan perilaku beresiko, namun dalam hal pengelaman mencegah responden dalam kategori sedang atau rentan yang akan mempengaruhi responden dalam efikasi dirinya dalam mencegah perilaku beresiko HIV/AIDS. begitu juga dengan aspek motivasi, walaupun dalam dimensi dorongan internal sudah dikatakan cukup tinggi namun dorongan eksternal pada aspek motivasi memiliki kecenderungan rentan dan inipun akan mempengaruhi dorongan yang ada dalam diri remaja mengingat usia remaja yaitu usia dimana banyak belajar hal yang baru dan lingkungan sangat mempengaruhi tumbuh dan kembang remaja. Meskipun pada aspek afeksi dan seleksi tergolong dalam kategori tinggi, namun demikian karena aspek motivasi dan kognitifnya akan sangat mempengaruhi proses efikasi diri, berdasarkan hal tersebut perlu adanya penguatan terkait motivasi dan juga kognisi dari remaja dalam efikasi diri nya untuk mencegah perilaku beresiko HIV/AIDS. hal ini didukung oleh pernyataan bandura 1994 bahwa pentingnya efikasi diri bagi seseorang yaitu penentu besarnya usaha dan daya tahan dalam mengatasi hambatan dan pengalaman.

\section{Aspek koginitif}

Aspek kognitif disini mencangkup pemahaman dan pengetahuan responden mengenai perilaku beresiko HIV/AIDS serta pengalaman mencegah. Pada aspek kognitif dimensi pengetahuan responden cukup tinggi dalam menjawab pernyataan benar dari setiap item pernyataan yang diberikan, terlihat dari jumlah yang menjawab benar lebih banyak dari yang menjawab salah, itu berarti pemahaman responden terhadap pengetahuan mengenai pencegahan perilaku beresiko HIV/AIDS cukup tinggi. Namun ada beberapa pernyataan yang banyak dijawab salah oleh responden yaitu mengenai menonton pornografi dan berciuman dapat menyebabkan HIV/AIDS serta perlunya berbicara mengenai hubungan seksual dengan teman (pacar).

Pendidikan mengenai seks masih cukup awam dikalangan remaja sehingga hal-hal tersebut jarang terbahas atau terajarkan hal tersebut sejalan dengan teori dari Minor dan Felomon (Suherman, 2012) bahwa berkaitan dengan pengetahuan tentang seks hampir setiap orang mempunyai pandangan dan pengertian 
sendiri-sendiri mengenai masalah seks. Bagi sementara orang masalah seks dipandang sebagai sesuatu yang bersifat suci dan rahasia, bagi orang lainnya masalah seks mungkin diartikan sebagai sesuatu yang jorok dan menjijika, bahkan ada pula orang yang memandang seks sebagai hal yang tabu dan terlarang dan, karena itu tidak layak untuk dibicarakan terbuka.

Pada aspek kognitif dimensi pengalaman mencegah responden pada kategori tinggi sebesar 13,19\% sedangkan pada kategori sedang sebesar 75,68\% dan pada kategori rendah sebesar $11,1 \%$. Responden dinilai kurang memiliki pengalaman dalam usaha pencegahan perilaku beresiko HIV/AIDS seperti komunikasi mengenai seks kepada teman(pacar) serta aktivitas yang mengarah pada pencegahan HIV/AIDS. hal hal mengenai komunikasi mengenai seks masih sangat tidak lazim untuk dibicarakan karena remaja menganggap bahwa hal tersebut tidak perlu dilakukan kurangnya pengalaman mengenai hal tersebut mempengaruhi remaja dalam mencegah perilaku beresiko HIV/AIDS.

\section{Aspek motivasi}

Aspek motivasi dalam efikasi diri merupakan dorongan bagi remaja dalam mencegah perilaku beresiko HIV/AIDS. pada aspek motivasi dimensi dorongan internal termasuk kedalam kategori tinggi yaitu sebesar $90,28 \%$ yaitu berarti mayoritas remaja memiliki motivasi dorongan internal yang cukup tinggi dalam mencegah perilaku beresiko HIV/AIDS.

Berbeda dengan dorongan internal pada aspek motivasi dimensi dorongan eksternal termasuk ke dalam kategori sedang sebesar $69,44 \%$ remaja dalam aspek motivasi dimensi dorongan eksternal memiliki kerentanan, dorongan eksternal berasal dari peran serta orang tua, sekolah dan juga media sosial dalam memotivasi remaja dalam usaha mencegah perilaku beresiko HIV/AIDS pada remaja.

Dapat digambarkan bahwa dalam aspek motivasi remaja dalam mencegah perilaku beresiko HIV/AIDS dalam dorongan yang ada dalam diri tinggi karena remaja mengetahui dan meyakini bahwa dirinya tidak ingin terjerumus kedalam pergaulan yang tidak sehat dan merasa perlu menyelamatkan masa muda dengan menjauhi perilaku beresiko namun dalam dorongan eksternal nya cukup rentan, dorongan eksternal berpengaruh cukup besar terhadap remaja mengingat dalam usia remaja 15-19 tahun berada pada fase remaja pertengahan. Menurut pinukas dalam (Hendriati, 2006), remaja pertengahan berada dalam fase yang memiliki tugas perkembangan masa pencarian jati diri serta ruang lingkup pergaulan yang semakin meluas dan mengenal lingkungan baru, jika dorongan yang ada didalam luar diri rentan akan sangat mempengaruhi motivasi remaja dalam usaha mencegah perilaku beresiko HIV/AIDS.

\section{Aspek afeksi}

Aspek afeksi merupakan keyakinan untuk mampu mengontrol emosi dan stress dengan baik dalam mencegah perilaku beresiko HIV/AIDS pada remaja. Pada aspek afeksi dimensi pengendalian emosi termasuk dalam kategori tinggi sebesar $59,72 \%$ dan pada kategori sedang sebesar $34,03 \%$ serta kategori rendahnya sebesar $6,25 \%$ remaja pada dimensi pengendalian emosi cukup tinggi dalam mengendalikan 
emosi yang ada dalam dirinya untuk mencegah perilaku beresiko HIV/AIDS hal ini terbukti melalui jawaban responden, namun ada beberapa item pernyataan yang ckup rendah skornya yaitu pernyataan remaja merasa takut dan kesulitan jika dihadapkan pada situasi yang menekan atau tidak menyenangkan. Hal tersebut sejalan dengan karakteristik dari remaja menurut (Hurlock, 1994) yang menyebutkan bahwa remaja merupakan masa dimana penuh dengan badai ketegangan (strong and stress) karena pada umumnya remaja menunjukkan perilaku emosional, mudah marah dan mudah putus asa serta mudah terpengaruh.

Dalam aspek afkesi dimensi mengatasi stress termasuk kedalam kategori tinggi yaitu sebesar $60,41 \%$ serta kategori sedang sebesar $32,63 \%$ pada dimensi ini remaja mayoritas memiliki coppyng stress yang cukup baik untuk menghadapi kesullitan dalam mencegah perilaku beresiko HIV/AIDS.

\section{Aspek seleksi}

Aspek seleksi ini merupakan pemilihan tindakan atau perilaku yang dilakukan oleh remaja dalam mencegah perilaku beresiko HIV/AIDS serta ketegasan untuk memilih sebuah aktivitas atau tindakan yang diyakininya baik dan bermanfaat. Pada aspek seleksi dimensi selektif termasuk kedalam kategori tinggi yaitu sebesar $79,87 \%$ serta pada kategori sedang sebesar $18,75 \%$ menunjukkan bahwa responden dalam penelitian ini memiliki kemampuan yang cukup tinggi dalam memilih aktivitas atau tindakan dalam mencegah perilaku beresiko HIV/AIDS. aspek seleksi dimensi ketegasan berada pada kategori yang tinggi yaitu sebesar $80,55 \%$ menandakan bahwa responden dalam penelitian ini cukup memiliki ketegasan dalam memilih aktivitas dan tindakan yang dilakukannya dalam mencegah perilaku beresiko HIV/AIDS.

\section{Analisis Kebutuhan}

Hasil penelitian mengenai efikasi diri remaja dalam mencegah perilaku beresiko HIV/AIDS di kota bandung menggambarkan bahwa masih terdapat kebutuhan-kebutuhan yang harus dipenuhi dalam rangka penanganan masalah dalam upaya pencegahan perilaku yang beresiko terhadap infeksi HIV/AIDS dikalangan remaja. Uraian kebutuhan dalam rangka meningkatkan pengalaman mencegah, dorongan eksternal yang ada dalam remaja serta pemberdayaan remaja guna mencegah perilaku beresiko HIV/AIDS yaitu:

a. Peningkatan kapasitas remaja

$$
\text { Peningkatan kapasitas remaja }
$$
melalui beberapa rangkaian kegiatan yang dapat memberikan edukasi terhadap remaja mengenai pentingnya pendidikan seks, mengenai HIV/AIDS serta pergaulan yang sehat dilingkungan remaja baik peer group, lingkungan keluarga serta sekolah ataupun kampus. Di beberapa lembaga pendidikan khususnya di kota bandung sudah ada beberapa yang menerapkan dan menjadikan pendidikan seks menjadi sebuah hal yang diajarkan namun belum semua menerapkannya.

b. Peningkatan motivasi remaja

Peningkatan motivasi remaja dapat dilakukan melalui beberpa rangkaian kegiatan seperti penyuluhan mengenai 
pentingnya menjaga dan masa muda agar terhindar dari perilaku yang dapat beresiko terkena HIV/AIDS ataupun konten konten di sosial media yang dapat membangun remaja untuk dapat memperoleh dukungan yang meningkatkan motivasi dari remaja.

c. Parenting terhadap orang tua

Pola asuh yang diterapkan oleh orang tua kepada anaknya yang menginjak usia remaja juga sangat mempengaruhi terhadap tumbuh dan kembang remaja itu sendiri, pendidikan seks juga perlu diterapkan pada tingkat keluarga dan menerapkan norma norma sosial keluarga sebagai agen sosialisasi tingkat pertama bagi remaja dalam menapaki dunia remaja yang penuh dengan belajar dan mencari jati diri remaja.

\section{Analisis Sumber}

Sistem sumber merupakan segala sesuatu yang dapat dimanfaatkan untik pemenuhan kebutuhan dalam upaya penanganan masalah. Allen pincus dan anne minahan dalam sukoco 2011 mengemukakan bahwa sistem sumber terdiri dari tiga golongan yaitu sistem sumber informal,formal dan kemasyarakatan. Sistem sumber yang dapat dimanfaatkan dalam penanganan masalah efikasi diri remaja dalam mencegah perilaku beresiko HIV/AIDS di kota bandung yaitu:

a. Sistem Sumber Informal

Sistem sumber informal atau sistem sumber alamiah merupakan sumber yang dapat memberikan bantuan berupa dukungan emosional, kasih saying dan perhatia atau bantuan lainnya. Sumber yang dapat dimanfaatkan dalam upaya penanganan masalah efikasi diri remaja dalam mencegah perilaku beresiko
HIV/AIDS di kota bandung yaitu keluarga dari pada remaja, guru disekolah serta lingkungan teman teman sebaya.

b. Sistem Sumber Formal

Sistem sumber formal adalah keanggotaannya dalam suatu organisasi atau asosiasi formal dimana sumber tersebut dapat memberikan pelayanan atau bantuan terhadap anggotanya. Sistem sumber formal yang terdapat dikota bandung yaitu forum komunikasi siswa (fokus) kota bandung dan komisi penanggulangan HIV/AIDS.

c. Sistem Sumber Kemaysarakatan

Sistem sumber kemasyarakatan merupakan lembaga-lembaga milik pemerintah atau swasta yang dapat memberikan pelayanan kepada masyarakat. Sistem sumber kemasyarakatanyang dapat diakses oleh seluruh lapisan masyarakat sistem sumber kemasyarakatan dalam pemenuhan kebutuhan dalam permasalahan efikasi diri remaja dalam mencegah perilaku beresiko HIV/AIDS di kota bandung adalag dinas pendidikan, dinas sosial kota bandung serta dinas pemuda dan olahraga kota bandung.

\section{KESIMPULAN}

Penelitian mengenai efikasi diri remaja dalam mencegah perilaku beresiko HIV/AIDS di kota bandung. Hasil penelitian yang telah dilakukan kepada 144 responden yang berusia 15-18 tahun memperoleh hasil penelitian yaitu bahwa efikasi diri remaja dalam mencegah perilaku beresiko HIV/AIDS dalam kategori sedang. Hal tersebut dapat dikatakan bahwa responden rentan untuk efikasi atau memiliki keyakinan diri yang akan menghambat remaja 
dalam pencegahan perilaku beresiko HIV/AIDS. sementara itu untuk mengetahui penyebab mengapa hasil dari penelitian ini termasuk kedalam kategori yang sedang peneliti akan merekap kembali hasil dari penelitian ini dari setiap aspek dan dimensi sehingga nantinya akan diketahui hal apa yang harus ditanggulangi dan ditangani agar efikasi diri remaja dapat meningkat.

Merujuk pada hasil penelitian, telah didapatkan hasil mengenai skor masing masing responden di tiap-tiap aspeknya. Aspek kognitif dalam hal pengetahuan responden dinilai mampu memahami dan mengetahui mengenai pencegahan perilaku beresiko, namun dalam hal pengelaman mencegah responden dalam kategori sedang atau rentan yang akan mempengaruhi responden dalam efikasi dirinya dalam mencegah perilaku beresiko HIV/AIDS. begitu juga dengan aspek motivasi, walaupun dalam dimensi dorongan internal sudah dikatakan cukup tinggi namun dorongan eksternal pada aspek motivasi memiliki kecenderungan rentan dan inipun akan mempengaruhi dorongan yang ada dalam diri remaja mengingat usia remaja yaitu usia dimana banyak belajar hal yang baru dan lingkungan sangat mempengaruhi tumbuh dan kembang remaja. Meskipun pada aspek afeksi dan seleksi tergolong dalam kategori tinggi, namun demikian karena aspek motivasi dan kognitifnya akan sangat mempengaruhi proses efikasi diri, berdasarkan hal tersebut perlu adanya penguatan terkait motivasi dan juga kognisi dari remaja dalam efikasi diri nya untuk mencegah perilaku beresiko HIV/AIDS.

Analisis kebutuhan pun dilakukan setelah melakukan analisis masalah, hasil yang didapat adalah perlunya peningkatan kapasitas remaja dan juga peningkatan motivasi remaja dalam mencegah perilaku beresiko HIV/AIDS yang merupakan pemberian pengetahuan serta pemahaman mengenai pencegahan perilaku beresiko serta meningkatkan motivasi dengan pemberian informasi dan juga dorongan agar dapat berhasil dalam usaha pencegahan perilaku beresiko HIV/AIDS. kebutuhan lainnya adalah sebuah wadah untuk dapat memfasilitasi orang tua dalam memberikan informasi mengenai parenting terhadap anak terkhusus usia remaja dalam pemberian edukasi mengenai pendidikan seks dalam keluarga.

Hasil dari analisis kebutuhan untuk memecahkan masalah memerlukan sumber untuk mendukungnya. Berdasarkan analisis sumber yang telah dilakukan terdapat tiga sistem sumber yang dapat digunakan yaitu sistem sumber informal, sistem sumber formal dan sistem sumber kemasyarakatan. Sistem sumber informal dapat diperoleh dari keluarga, teman sebaya serta lingkungan rumah dan guru. Sistem sumber formal ialah komisi penanggulangan HIV/AIDS dan forum komunikasi siswa (fokus) kota bandung, serta sistem sumber kemasyarakatan dapat diperoleh dari dinas sosial, dinas pendidikan serta dinas pemuda dan olahraga kota bandung.

Berdasarkan masalah, kebutuhan dan sistem sumber yang dapat diakses maka peneliti mengusulkan rencana intervensi berupa program untuk efikasi diri remaja dalam mencegah perilaku beresiko HIV/AIDS yaitu program "Peningkatan Kapasitas dan Motivasi Remaja Dalam Mencegah Perilaku Beresiko HIV/AIDS Melalui Komunikasi, Edukasi Serta Informasi". Hal ini bertujuan untuk Meningkatkan pengetahuan dan pemahaman remaja mengenai pencegahan perilaku beresiko HIV/AIDS, Meningkatkan motivasi dari 
remaja dalam usaha mencegah perilaku beresiko HIV/AIDS, dan Meningkatkan pengetahuan dan kesadaran dari orang tua mengenai parenting remaja pentingnya pendidikan seks di lingkungan keluarga dan penanaman norma dan nilai nilai kepada remaja.

\section{DAFTAR PUSTAKA}

Alwisol. (2009). Psikologi Kepribadian. Malang: UMM Press.

Abdi dan Usman Rainse. (2012). Metodologi Penelitian Sosial dan Ekonomi Teori dan Aplikasi. Bandung: Alfabeta.

Bandura, A. (1997). Self Efficiacy: The Exercise Of Control. New York: W.H. Freeman and Company.

Bandura, A. (2002). Self - Efficiacy: The Exercis Of Control. New York: H. Freeman and Company.

Baron, Robert, A., \& Byrne.D. (2012). Psikologi Sosial (Vol. 2). Jakarta: Erlangga.

Biglan, Anthony, Brennan, A, P., Foster, Holder, S. L., \& D, H. (2004). Helping Adolescents At Risk: Prevention Of Multiple Problem Behaviours. Guiford Press.

BPS, \& DEPKES, R. (2015). Survey Situasi Perilaku Tertular HIV Di Indonesia. Jakarta: SSP 2004-2005.

Dubois, B., \& Miley, K. K. (2005). Social Work An Empowered Proffesion. USA: USA Pearson.

Fagan. (2006). Psikologi Remaja. Jakarta: PT Gramedia.

Fauziah, Y., \& Syahputra, R. (2019). Hubungan Antara Efikasi Diri Dengan Manajemen Perawatan Diri Pada Penderita Hipertensi Di Puskesmas Indrapura Kabupaten Batubara. Journal of Midwifery Senior.

Givaudan, Martha, Vijen, V. D., Jr, F., Poortingai, H, Y., . . . Susan. (2007). Effect Of A School- Based Life Skill And HIVPreverention Program For Adolescents In Mexican High School 1. Journal Of Applied Social Psychology.

Gufron, M. N., \& Risnawati, R. (2010). Teoriteori Psikologi . Jogjakarta: AR-Ruzz Media.
Hendriati, A. (2006). Psikologi Perkembangan Pendekatan Ekologi Kaitannya Dengan Konsep Dan Penyesuaian Diri Pada Remaja. Bandung: PT Refika Aditama.

Hurlock, E. B. (1994). Psikologi Perkembangan (Suatu Pendekatan Sepanjang Rentan Kehidupan). Jakarta: Erlangga.

Kadushin, \& A. (1974). Child Welfare Service. New York.

Lee, Yi-Hui, Salman, Patrick, A., \& J., J. (2009). Preverentive Self Efficiacy, Depressive Symptons, And Risky Sexsual Behaviour In Adolescents. A CrossSectional Questionare.

Luszczynska, Aleksandra, Guttiereze-Dona, Benicio\&Schwarzer, \& Raif. (2005). General self-efficiacy in various domains of human functioning: Evidence form five countries. International Journal of Psychology, 80-89.

Nazir, M. (2014). Metode Penelitian. Bogor: Ghalia Indonesia.

Monkd, F.J, Knoers, A.M.P, Haditono, \& S.R. (2002). Psikologi Perkembangan Pengantar Dalam Berbagai Bagiannya. Gajah Mada University Pers, 262.

Nursalam, \& Ninuk. (2007). Asuhan Keperawatan Pada Pasien Terinfeksi. Jakarta: Salemba Medika.

Santrock. (2003). Adolesence. Perkembangan Remaja (Vol. VII). Jakarta: Erlangga.

Sarwono, S. W. (2003). Psikologi Remaja. Jakarta: Raja Grafindo Persada.

Setyoadi, \& Endang. (2002). Strategi Pelayanan Keperawatan Bagi Penderita AIDS . Yogyakarta: Graha Ilmu.

Soehartono, I. (2015). Metode Penelitian Sosial Suatu Teknik Penelitian Bidang Kesejahteraan Soisal Dan Ilmu Sosial. Bandung: PT Remaja Rosdakarya.

Sugiyono. (2018). Metode Penelitian Kuantitatif. Bandung: Alfabeta.

Suherman, H. (2012). Pendidikan Seks Yang Sehat Untuk Anak-Anak. Psikologika, 17.

Susilowati, E., \& Dewi, K. (2019). Living Experience Of Women With Hiv/Aids In West Java Indonesia. Indonesian Journal of Social Work, 3(1). 
Sukoco, D. H. (1998). Profesi Pekerjaan Sosial Dan Proses Pertolongannya. Bandung: Koperasi Mahasiswa Sekolah Tinggi Kesejahteraan Sosial (STKS) Bandung.

\section{Internet}

Infodatin Situasi Penyakit HIV AIDS Di Indonesia, Pusdatin, Kementrian Kesehatan, 2019

Https://Bandungkota.Bpss.Go.Id 